\title{
Marketing in an experiential perspective: Toward the "Experience Logic"
}

\author{
Tonino Pencarelli
}

1. This editorial aims to show shortly how the experiential logic can be used to renew the most known marketing perspectives, by directing them towards new management approaches which, starting from the customer experience, can find new ways to create, communicate, and deliver value. We want to reflect about a new vision of marketing, starting from the traditional goods logic, discussing services marketing contributions, and ending with the experiential and experience marketing theories. We discuss the differences between experiential and experience marketing approaches, in order to go towards a new common vision: the "marketing-driven experience logic".

The studies on the evolution of the marketing concept traditionally emphasize how it has been evolving over time, in parallel with the change in companies' managerial perspectives. The concept of marketing has switched from a production and product orientation (in the 50s and 60s), to a sales orientation (in the 70s), and recently, to market and customer orientations, until it assumed a holistic relational approach, involving all the company stakeholders (Gummesson, 1999).

In a world where intangible factors and services are pervasive, the Service Marketing literature (Vargo and Lush, 2004; Vargo and Akaka, 2009; Grönroos and Gummerus, 2014) points out, in particular, the need to go beyond the classic mental models and managerial marketing approaches guided by the goods logic in order to take into account the differences in the customer approach imposed by the particular characteristics of the service economy, such as simultaneity between production and consumption, intangibility, heterogeneity, and perishability of product, no stocks, no proprietary portability of pension benefits and customer participation in service management processes. The emerging and very

Mercati \& Competitività (ISSN 1826-7386, eISSN 1972-4861), 2017, 2

DOI: 10.3280/MC2017-002001 
wide-ranging debate surrounding this issue leads both the preliminary Service Logic perspective (Grönroos, 2011) and, more recently, the perspective of the Service Dominant Logic (Vargo and Lusch, 2004; Vargo and Akaka, 2009; Lush and Nambisan, 2015; Greer et al., 2016), albeit with different emphases (Grönroos and Gummerus, 2014), to highlight some distinctive features of Service Marketing: 1) a product usually has no value in itself (Gummesson, 2008); therefore, the customer is always a cocreator of value (Cova et al., 2011); 2) the concept of customer value refers not so much to the exchange value, as the contextualized use value, alluding to categories such as value-in-use and value-in-context, cited by Gummerus by Grönroos (2014), or experiential value (Greer et al., 2016); 3 ) the company has to interact with the customer's value creation process in order to generate value (O'Brien, 2007; Grönroos and Gummerus, 2014; Greer et al., 2016), i.e., it has to plan and manage the platform of interactions in order to support the value creation for and with the customer (Grönroos and Strandvik, 2008).

An evolution of these perspectives brings about a vision in which the supply processes are no longer central in managerial practices and theoretical analysis and there is a diffusion of a broader and customercentric vision (Customer Dominant Logic). As cited by Heinonen et al., (2010), this vision aims to understand and to deepen how the value emerges for the customer and how the customer builds the value and sense experience before, during, and after the use of the service. Marketing gradually shifts the focus, from the perspective of supply, service processes, and enterprise, implicit in Service Marketing approaches, to the customer's perspective and his/her overall experience. The focus on the customer converges towards the overall focus on the customer's consumption experience, not only as a consumer, but also as a member of a community, a family, or a company. Ultimately, the value-in-use is qualified by the customer in terms of the overall experience he/she lived, within the specific environment and personal situation. This does not necessarily have to be extraordinary and unique, but can also refer to daily consumption forms, outside of market relations (Bruckner, 2000; Carù and Cova, 2003).

2. As a result of the post-industrial society, we are shifting from a service economy to an economy of experiences, which enriches the value of all goods and services, leading to the birth of a new economic sector: the "experiences industry". There emerges a new perspective of consumer behavior, mainly focused on the analysis of consumption experiences (Gentile et al., 2007; Zomerdijk and Voss, 2010; Walls e al., 2011; Achrol, Kotler, 2012). In this context, Service Marketing theories have progressively been enriched by Experience Economy (Pine and Gilmore, 
1999; Sundbo and Sorensen, 2013) and Experiential Marketing (Schmitt, $1999,2003)$ contributions. What is progressively emerging is the importance of the consumption experience value (Palmer, 2010), which is an experiential value (Value-in-Experience), that has its roots in the concepts of Value-in-Use (Vargo and Lusch, 2004), Value-in-Possession (Richins, 1994) and in the more recent formulations of Value-in-Context (Vargo and Akaka, 2009). It takes into account the deep difference between consumption experience and consumer experience (Carù, Cova, 2003, p. 198). Holbrook (1999, p. 9) states that consumer value "resides not in the product purchased, not in the brand chosen, not in the object possessed, but rather in the consumption experience( $s$ ) derived therefrom", to mean that experiences are emphasized as vehicles for delivering positive customer value. Scholars point out the need for marketing processes within the economy of experiences to focus on customers' experience rather than on goods or services: in fact, the experiential approaches recognize that customers make consumption choices guided by emotions and feelings as well as by rational thinking. Employing a marketing perspective, Schmitt (1999) stated that experiences are private, personal events that occur in response to some stimulation and involve the entire being as a result of observing or participating in an event. Schmitt (2003, p. 17) identifies the Customer Experience Management as the customer-centric process of strategically managing a customer's entire experience with a product or company. The logic of experiential consumption and of the experiential marketing (Schmitt, 1999, 2003) suggests that companies should develop an "experiential" platform capable of offering an Experiential Value Promise which focuses on customers' experience (Carù and Cova, 2007; Schmitt, 1999; Holbrook and Hirschman, 1982).

A more extreme interpretation of the concept of experience arrives at the new experience economy model (Pine and Gilmore, 1999), which identifies the experience as something more than a category of attributes to enrich and differentiate traditional products (raw materials, goods and services). According to their model, experience is, above all, a new and different offer category for which a specific and new marketing approach, called Experiences Marketing (Fortezza and Pencarelli, 2011; Same and Larimo, 2012), is needed. Experiences marketing is nothing more than an approach applied to highly immaterial and highly experiential products which we may also call experience-products, examples of which are the tourism products (Pencarelli and Forlani, 2016; Sorensen and Jensen, 2015). The new marketing approach innovates the supply forms, focusing on building (staging) original, unique, engaging, possibly unforgettable, experiential packages, but it also renovates the other operational marketing policies, such as prices, communication, and distribution. The experiences economy model explains that companies may be considered to be 
operating in the experiences business (where the supply of experiences is of higher value than that of goods and services according to an economic value progression path), when experiences are staged for a fee. Therefore, if the experiences are offered as add-ons to goods and services or are free, following a differentiation strategy, the supply form may be included in the experiential logic, but the firms will not be seen as acting in the experiences business. When a company acts in the experiences business, the marketing model should aim to understand the types of experiences sought by customers and consequently, to set up experiential solutions to meet their needs. Tour packages are good examples of experiential value propositions which tourists may decide to purchase or to self-produce. Focusing on experiences, whether they are conceived as products (Pine and Gilmore, 1999) or as a consumption experience (Schmitt, 2003), means admitting that the company supply value "springs from the customer's experience." Therefore, value is not properly created until the offer is consumed and experienced by consumers (Prahalad and Ramaswamy, 2004), who should be treated as actors starring in the construction of value (Boswijk et al., 2012). Lastly, it means recognizing that the value is determined less during the service encounters between customer and service provider, and more during the experience encounters and, above all, during fruition of the experiential offer.

3. If we accept the concept of value-in-use in the sense of customers' experiences and we put the experiential dimension at the center of marketing strategies, it becomes clear that the logic of services should be surpassed and integrated by the experience economy perspective. This perspective considers experiences as the true source of value-in-use contextualized for the customer and suggests the adoption of an innovative marketing management approach which would follow the evolution of consumption right up to the experiences economy. Experience Economy may refer to a new marketing model based on the logic of the experience (Experience Logic), Pencarelli et al. (2015). A marketing approach based on Experience Logic can embrace what is proposed by the Experience Economy (Pine and Gilmore, 1999; Pencarelli et al., 2015), as well as by the Experiential Marketing model (Schmitt, 1999, 2003), integrating them with the literature inspired by the Service Logic (Grönroos, 2011; Grönroos and Gummerus, 2014) and the Service Dominant Logic (Vargo and Lusch, 2004). After all, Service Management processes are essential to the generation of value through customized experiences. According to the experiential perspective, managerial processes are asked to arrange for new activities in order to create value. Such activities should not ignore service processes, but use them to set up higher value offers, such as experiences. Thanks to the integration of service and experience economy perspectives, 
an innovative conceptual approach to "experience driven logic" marketing may be adopted. The new approach:

- identifies the economic supply categories proposed by Pine and Gilmore (1999): raw materials, goods, services, experiences, transformations, and considers these categories as possible outputs used to define the object of economic exchanges between actors according to the logic of the economic value progression;

- assumes the individual's experience as a value analysis unit and as the aim of marketing processes ("value is uniquely, experientially, and contextually determined and perceived by customers", Gummerus, Grönroos, 2014, p. 207). After all, when customers consume a product, they always have a good, bad, or indifferent experience, regardless of the object of purchase. The key point is how effectively a company is able to manage the experience, offering a balanced mix of functional and emotional benefits to consumers (Berry et al., 2002);

- describes the experience as a complex and multidimensional construct, based on five characteristics (Andersoon and Andersoon, 2013, pp. 8497): learning, which as it grows, increases consumption of the product; uniqueness, due to the intangible content of the experience; strong dependence and connection with the environment and with the location in which the experience is enjoyed (as happens in tourism experiences); interdependency between the spheres of activity of the producer and of the consumer and interdependence among consumers, generating network economies; inability to store the supply (as for services);

- brings out different dimensions of customer value in the experiential value perspective, such as: value-in-exchange, which is linked to the price paid; value-in-possession, which is related to the use of the product; value in use, which is linked to the consumer's perception during the consumption of a product, or to the idiosyncratic, experiential, contextual, and meaning laden value. Customer value- inexperience can therefore be defined as the "customer's perception of value over the entire course of the customer experience" (Turnbull, 2009);

- acknowledges that different economic actors take part in the customer's value creation process, according to an Actor to Actor value constellation and ecosystem service perspective (Lush and Nambisan, 2015; Greer et al., 2016), which goes beyond the boundaries of individual organizations and single entities, to emphasize the role of supply systems, of value systems, and of consumer systems;

- identifies the need to ground the marketing processes on the network theory, i.e., based on a perspective of many-to-many marketing and whose central objective is to create value and to satisfy all stakeholders (Gummesson, 1999; 2008); 
- divides the process of value creation into three spheres: the supplier's sphere, the customer's sphere (alone or in interaction with others), and the joint sphere which is the co-creation platform of the suppliers', the customers' and any other partner's experience (Grönroos and Gummerus, 2014, p. 218);

- uses the customers' skills to facilitate their involvement in the value cocreation processes; this implies some basic principles: reciprocal access of the consumers' world with the production world; dialogue between the two worlds through shared codes and languages; transparency regarding companies' use of customer resources; focus and management of risks associated with the processes of value co-creation (Boswijk, 2012, p. 130);

- integrates in a unitary experiential value perspective both experiential marketing (enriched experience goods and services) and experiences marketing.

In short, the comprehension of the experience logic of marketing can provide new managerial perspectives on the role of the company in creating customer value.

\section{References}

Achrol R.S., Kotler P. (2012). Frontiers of the marketing paradigm in the third millennium. Journal of the Academy marketing Science, doi:10.1007/s11747-0110255-4.

Andersoon D.E., Andersoon A. (2013). The Economic value of experience good. In: Sundbo J., Sorensen F. (2013). Handbook on the Experience Economy. Edward Elgar, UK.

Berry L.L., Carbone L.P., Haeckel S.H. (2002). Managing the Total Customer Experience. Research Future, April 15, Spring.

Boswijk A., Thijssen T., and Peelen E. (2012). Economy of Experiences. Amsterdam: Centre of Economy of Experience.

Carù A. and Cova B. (2003). Revisiting Consumption Experience: a More Humble but Complete View of the Concept. Marketing Theory, 3, 2: 267-287, doi: $10.1177 / 14705931030032004$.

Cova B., Dalli D., Zwick D. (2011). Critical perspectives on consumers' role as 'producers': Broadening the debate on value co-creation in marketing processes. Marketing Theory, doi: 10.1177/1470593111408171.

Fortezza F. and Pencarelli T. (2011). Experience marketing: specific features and trends. The Wish Days case study. Journal of Marketing Trends, 1: 57-69.

Gentile C., Spiller N., Noci G. (2007). How to Sustain the Customer Experience: an Overview of Experience Components that Co-create Value With the Customer. European Management Journal, 25(5): 395-410, doi:10.1016/j.emj.2007.08.005.

Greer R.C., Lush R.F., Vargo S.L. (2016). Key managerial insights from service-dominant (S-D) logic. Organizational Dynamics, in press doi: 10.1016/j.orgdyn.2015.12.004. 
Grönroos C. (2011). Value co-creation in service logic: A critical analysis. Marketing Theory, 11(3): 279-301, doi: 10.1177/1470593111408177.

Grönroos C., Gummerus J. (2014), The service revolution and its marketing implications: service logic vs service-dominant logic. Managing Service Quality, 24(3): 206-229, doi: 10.1108/MSQ-03-2014-0042.

Grönroos C., Strandvik T. (2008). The interaction concept and its implications for value creation and marketing in service business. In: Antila, Mai \& Rajala, Arto (eds.). Fishing with busines nets - keping thoughts on the horizon. Helsinki School of Economics, Helsinki.

Gummesson E. (1999). Total relationship marketing: experimenting with a synthesis of research frontiers. Australasian Marketing Journal, 7(1): 72-85, doi: 10.1016/S1441-3582(99)70204-1.

Gummesson E. (2008). Extending the service-dominant logic: from customer centricity to balanced centrity. Journal of the Academy of marketing, 36: 15-17, doi: 10.1007/s11747-007-0065-x.

Heinonen K., Standvik T., Mickelsson K.J., Edvardsson B., Sundstom E. (2010). A customer-dominant logic of service. Journal of Service Management, 21(4), doi: 10.1108/09564231011066088.

Holbrook M.B. and Hirschman E.C. (1982). The experiential aspects of consumption: consumer fantasies, feelings, and fun. Journal of consumer research, 9: 132-140, Stable URL: — http://www.jstor.org/stable/2489122.

Holbrook M. B. (1994). The Nature of Customer Value: An Axiology of Services in the Consumption Context. In Rust R. and Oliver R.L. (ed.). Service Quality: New Directions in Theory and Practice. Thousand Oaks: SAGE Publications.

La Salle D., Britton T.A. (2003). Priceless: Turning ordinary products into extraordinary experiences. Boston: Harvard Business School Press.

Lush R.F., Nambisan S. (2015). Service Innovation: a Service-Dominant Logic Perspective. Mis Quarterly, 39(1), march.

McColl-Kennedy J.R., Gustafsson A., Jaakkola E., Klaus P., Radnor Z.J., Perks H., Friman M. (2015). Fresh perspectives on customer experience. Journal of Services Marketing, 29(6/7): 430-435, doi: 10.1108/JSM-01-2015-0054.

Palmer A. (2010). Customer experience management: a critical review of an emerging idea. Journal of Services Marketing, 24(3): 196-208, doi: 10.1108/08876041011040604.

Pencarelli T., Forlani F., Dini M. (2015). Marketing of traditional-local products in the experiential perspective: the case of the truffle market. In: Weber Y., Tsoukatos E. \& Maizza A. Specialized conference of the EuroMed Academy of Business, Lecce.

Pencarelli T. and Forlani F., Marketing of touristic districts - viable systems in the experience economy, Sinergie Italian Journal of Management, 101: 199-238, doi 10.7433/5101.2016.12.

Pine B.J., Gilmore J.H. (1999). The experience economy: work is theatre \& every business a stage. Boston: Harvard Business School Press.

Prahalad C.K., Ramaswamy V. (2004). Co_creation experiences: The next practice in value creation. Journal of interactive marketing, 18(3): 5-14, doi: 10.1002/dir.20015.

Richins M.L. (1994). Valuing Things: The Public and private meanings of Possessions. Journal of Consumer Research, 21(3): 504-21, Stable URL: http://www.jstor.org/stable/2489689.

Same S., Larimo J. (2012). Marketing Theory: Experience Marketing and Experiental Marketing. International Scientific Conference, Business and Management, May, 10-11, Vilnius, Lituania, doi:10.3846/bm.2012.063. 
Schimtt B.H. (1999). Experential Marketing:How to Get Customers to Sense, Feel, Think, Act and Relate to Your Company and Brands. New York: The Free Press.

Schimtt B.H. (2003). Customer Experience Management: A Revolutionary Approach to Connecting with Your Customers. Hoboken, NJ; John Wiley \& Sons, Inc.

Sundbo J., Sorensen F. (2013). Introduction to the experience economy. In: Sundbo J., Sorensen F. Handbook on the Experience Economy, Edward Elgar: UK.

Turnbull J. (2009). Customer Value-in-Experience, Theoretical foundation and research agenda. Australian and New Zealand Marketing Academy Conference, Melbourne, ANZMAC proceedings: sustainable management and marketing conference, p.1-8, http://hdl.handle.net/1959.14/174296.

Vargo S.L., Akaka M.A. (2009). Service-dominant logic as a foundation for service science: clarifications. Service Science, 1(1): 32-41, doi: 10.1287/serv.1.1.32.

Vargo S.L., Lusch R.F. (2004). Evolving to a new dominant logic for marketing. Journal of marketing, 68(1): 1-17, doi: 10.1509/jmkg.68.1.1.24036.

Walls A.R., Okumus F., Wang Y.R. \& Kwun D.J.W. (2011). An epistemological view of consumer experiences. International Journal of Hospitality Management, 30(1): 10-21, doi: 10.1016/j.ijhm.2010.03.008.

Zomerdijk L.G. and Voss C.A. (2010). Service design for experience-centric services. Journal of Service Research, doi: 10.1177/1094670509351960. 